\title{
LAPAROSCOPIC VERSUS OPEN REPAIR OF INGUINAL HERNIA
}

\author{
Žilvinas Dambrauskass ${ }^{1,2}$, Lina Pankratjevaitė ${ }^{1}$, Vaidotas Bogusevičius ${ }^{1}$, Antanas Mickevičius ${ }^{1}$ \\ ${ }^{I}$ Department of Surgery, Lithuanian University of Health Sciences, Kaunas, Lithuania, \\ ${ }^{2}$ Institute for Digestive System Research, Lithuanian University of Health Sciences, Kaunas, \\ Lithuania
}

Key words: laparoscopic hernia repair, open hernia repair, postoperative pain, complications, outcomes.

\begin{abstract}
Summary
Background and objective. Inguinal hernia repair is one of the most common general surgery procedures. Laparoscopic repair is technically more demanding, though it has been shown to be superior in terms of pain and discomfort, however, there is no apparent difference in recurrence between laparoscopic and open mesh methods of hernia repair. Over the years we see a relatively slow increase of laparoscopic procedures and even scepticism of the patients; thus we decided to test the hypothesis that more demanding and costly laparoscopic surgery has little benefits over the open procedure. The aim of our study was to compare postoperative pain, short- and long-term outcomes after laparoscopic hernia repair and conventional open hernia repair.

Results. Laparoscopic procedure was significantly more often performed for the patients, who were younger, had shorter history of disease. The mean operative time for laparoscopic inguinal hernia repair was significantly longer than for open repair $(\mathrm{p}=0.02)$. The pain score for laparoscopic surgery was significantly lower according to VAS on day $1,2,3$ (overall $p \leq 0.002$ ). The patients in the laparoscopic group required significantly lower doses of narcotic analgesics on the third postoperative day; the doses of nonsteroidal anti-inflammatory drugs were also significantly lower on the second and third postoperative day in this group. The postoperative hospital stay was shorter after laparoscopic repair $(\mathrm{p}=0.01)$. Sixty-four patients $(71.11 \%)$ completed follow-up at one year after the operation. Nine $(14.06 \%)$ of them had postoperative complications and eight of them were after open hernia repair. Two patients $(3.1 \%)$ were re-operated (both
\end{abstract}

patients were treated by Lichtenstein hernioplasty): one for inguinal hernia recurrence, another for testicular necrosis.

Conclusions. The patients from laparoscopic group had significantly shorter postoperative pain duration $(p=0.019)$, returned to daily activity slightly earlier and had better satisfaction with the operation comparing with the patients who undergone open surgery $(p=0.915, p=0.893)$, but the duration of the sick leave (time off from work) was similar in both hernia repair group $(p=0.260)$. Data shows that laparoscopic hernia repair has advantages in terms of post-operative pain intensity and duration, as well as risk of complications and patient satisfaction.

\section{Introduction}

Inguinal hernia repair is one of the most common procedures in general surgery. The repair of hernia can be carried out as an open surgery or laparoscopically. Numerous inguinal hernia open repair techniques are described: Bassini, Lichtenstein (tension-free), Shouldice, McVay, etc. There are two standardized laparoscopic inguinal hernia repair methods: transabdominal preperitoneal (TAPP) and total extraperitoneal (TEP). Number of laparoscopic inguinal hernia repair procedures grows constantly during the last decade in Lithuania. According Hospital of Lithuanian University of Health Sciences (LUHS) data, from 2008 September to 2011 September 648 inguinal hernia repair procedures were performed: $182(28.09 \%)$ of them was done laparoscopically and $466(71.91 \%)$ conventionally (open surgery). Meanwhile during the period from 2011 September to 2014 September 720 hernioplasty were performed: $228(31.67 \%)$ of them were done laparoscopically and $492(68.33 \%)$ of the patients undergone open surgery. Some randomized studies comparing laparoscopic versus open inguinal hernia repair have confirmed that laparoscopic approach is associated with reduced postoperative pain and earlier return to work (1-8), laparoscopic hernia 
repair is associated with better cosmetic results than conventional open surgery (4). One more advantage of the laparoscopic technique is ability to detect a contralateral inguinal defect and repair it through the same incision at the same time (9). Laparoscopic procedure, however, requires general anaesthesia; operative time and learning curve are longer $(5,8,10,11)$.

So what surgery technique to choose for hernia repair: laparoscopic or open surgery? The guidelines of the European Hernia Society, the International Endohernia Society, and the European Association of Endoscopic Surgery suggest: when there is primary unilateral inguinal hernia in men- laparoscopic or open surgery can be performed; when there is primary unilateral inguinal hernia in woman or primary bilateral inguinal hernia in men and woman laparoscopic surgery is suggested (TEP or TAPP)(12). When there is hernia recurrence and previous operation was open, surgeon should choose TEP or TAPP; if previous was laparoscopic/endoscopic procedure then Lichtenstein technique should be used (12).

The most common techniques we use for inguinal hernia in our hospital (Hospital of Lithuanian University of Health Sciences, LUHS) are: open surgery (Shouldice or Lichtenstein methods) or laparoscopic TAPP procedure.

The aim of our study was to compare postoperative pain, short- and long-term outcomes after laparoscopic hernia repair and conventional open hernia repair.

\section{Material and methods}

This prospective study examined 90 consecutive patients, who underwent inguinal hernia repair surgery at LUHS between January 2013 and October 2014. Age, sex, body mass index, hernia type, duration of presence of symptoms was recorded before surgery. Duration of operation and postoperative pain first, second and third day after the operation as well as the presence of complications (fever, wound infection), duration of postoperative pain, comfort after the procedure, reoperation rate, the time of the sick leave, duration of returning to normal activity, and recurrence rate were investigated during follow-up visits after the operation. The severity of postoperative pain was evaluated using visual analogue scale (VAS) $-10 \mathrm{~cm}$ horizontal line with endpoints, labelled "no pain" at $0 \mathrm{~cm}$ and "worst pain possible" at $10 \mathrm{~cm}$. Patients were asked to mark on the line representing the mean pain that they had experienced that day. The use of analgesia was recorded.

The final records were made at one year after the operation follow-up visit. The results were compared between two groups - laparoscopic and open hernia repair.

The statistical analysis was performed using SPSS for
Windows, release 17.0 (SPSS, Chicago, Ill., USA). Comparison between open and laparoscopic surgery groups was performed using the $\chi^{2}$ test and Mann- Whitney test as appropriate. Significance was defined as a $p$ value $<0.05$.

The study was approved by the local ethics committee (No. BEC-LSMU(R)-13). All the patients have agreed to participate in this study.

\section{Results}

There were $91.1 \%$ (82) men and 8.9\% (8) - women included in the study. The mean age of the patients was $58.11 \pm 17.68$ years. Sixty-four patients $(71.11 \%)$ underwent open hernia repair and twenty-six patients (28.89 $\%$ - laparoscopic TAPP hernia repair. Eighty-five patients (94.44\%) had unilateral (52 right side; 33 left side) hernia and five patients $(5.56 \%)$ bilateral hernia. There were sixty patients $(93.75 \%)$ with unilateral hernia and four patients $(6.25 \%)$ with bilateral hernia in open hernia repair group and twenty-five (96.15\%) unilateral and one patient (3.8\%) with bilateral hernia in laparoscopic hernia repair group.

The baseline characteristics of the patients are shown in Table 1. Surgery type (open or laparoscopic hernia repair) did not depend on patient's gender $(\mathrm{p}=0.686)$, body mass index or the side of hernia (unilateral or bilateral) $\mathrm{p}=0.654$. For patients, who were younger, had shorter time of history of symptoms laparoscopic procedure was perfor-

Table 1. Comparision of main characteristic according to hernia surgery treatment group

* BMI - Body mass index

\begin{tabular}{|l|c|c|c|}
\hline & $\begin{array}{c}\text { Open hernia } \\
\text { repair }\end{array}$ & $\begin{array}{c}\text { Laparoscopic } \\
\text { hernia repair }\end{array}$ & P value \\
\hline Age (years) & $61.25 \pm 17.59$ & $50.38 \pm 15.69$ & 0.007 \\
BMI* $\left(\mathrm{kg} / \mathrm{m}^{2}\right)$ & $26.08 \pm 4.21$ & $25.98 \pm 3.82$ & 0.993 \\
$\begin{array}{l}\text { Duration of symptoms } \\
\text { before hospitalization } \\
\text { (months) }\end{array}$ & $34.94 \pm 68.38$ & $9.02 \pm 14.32$ & 0.043 \\
$\begin{array}{l}\text { Duration of surgical } \\
\text { procedure (min) }\end{array}$ & $96.48 \pm 40.48$ & $110.19 \pm 33.92$ & 0.020 \\
\hline
\end{tabular}

Table 2. Postoperative VAS pain score

* The pain score for laparoscopic surgery was significantly lower on the VAS on first, second and third day after the procedure.

\begin{tabular}{||r|c|c|c|}
\hline & $\begin{array}{c}\text { Open her- } \\
\text { nia repair }\end{array}$ & $\begin{array}{c}\text { Laparoscopic } \\
\text { hernia repair }\end{array}$ & P value \\
\hline The mean pain score: & & & \\
first day & $4.07 \pm 1.43$ & $2.69 \pm 1.43$ & 0.000 \\
second day & $2.70 \pm 1.48$ & $1.59 \pm 1.33$ & 0.000 \\
third day & $1.81 \pm 1.12$ & $0.57 \pm 0.35$ & 0.002 \\
\hline & & & \\
\hline
\end{tabular}


med significantly more often. Operating time for laparoscopic procedure was significantly longer than open hernia repair. Thirty-seven $(41.1 \%)$ patients had direct hernia, forty-eight $(53.4 \%)$ - indirect hernia, two $(2.2 \%)$ - bilateral

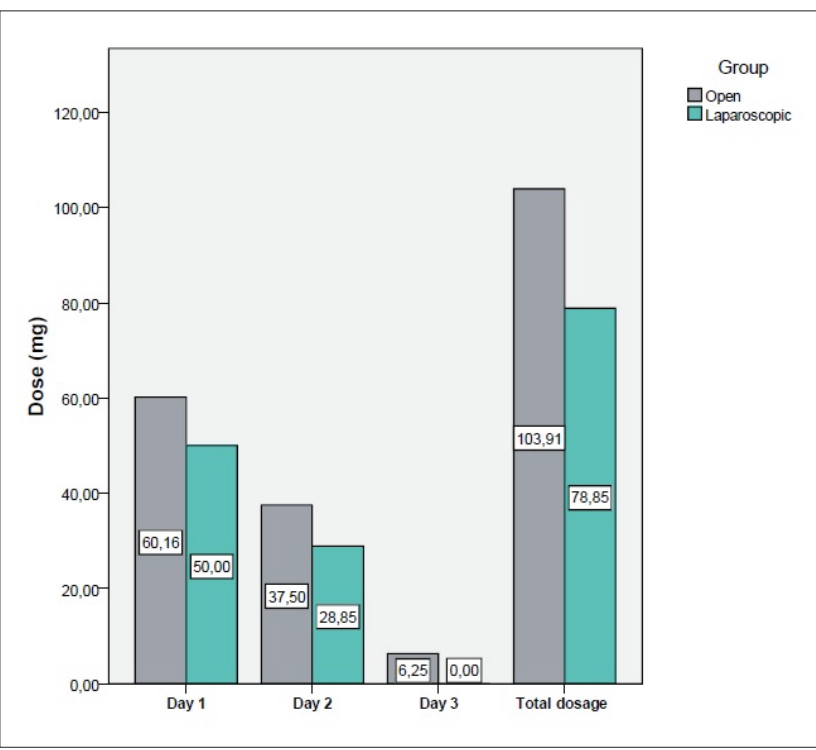

Figure 1. Use of opioids* postoperatively. The consumption of narcotic analgesics all three days was lesser in laparoscopic group.

*-Opioids: Pethidin - Dolobloc, Dolsin

Table 3. Comparision of the recurrence and of the complications of hernia repair after the patients left the hospital

* Online source of The Clavien-Dindo classification - http://www.assessurgery.com/ clavien-dindo-classification/)

\begin{tabular}{l|l|c|l|l|}
\hline & $\begin{array}{l}\text { The Clavien-Din- } \\
\text { do classification* } \\
\text { (The grade) }\end{array}$ & $\begin{array}{l}\text { Open her- } \\
\text { nia repair } \\
(\mathbf{n = 4 2 )}\end{array}$ & $\begin{array}{l}\text { Laparoscopic } \\
\text { hernia repair } \\
(\mathbf{n = 2 2})\end{array}$ & $\begin{array}{l}\text { Total } \\
\text { (n=64; \%) }\end{array}$ \\
$\begin{array}{l}\text { No. of complication cases (n=) } \\
\text { Fever }\end{array}$ I & 4 & 0 & $4(6.2 \%)$ \\
Wound infection & I & 5 & 0 & $5(7.8 \%)$ \\
Wound separation & I & 0 & 0 & $0(0.0 \%)$ \\
Neuralgia & I & 1 & 1 & $2(3.1 \%)$ \\
Testicular necrosis & IIIb & 1 & 0 & $1(1.5 \%)$ \\
Recurrence & IIIb & 1 & 0 & $1(1.5 \%)$ \\
Re-operated & & 2 & 0 & $2(3.1 \%)$
\end{tabular}

Table 4. Comparision of long-term outcomes of hernia repair

\begin{tabular}{|l|l|l|l|}
\hline & $\begin{array}{l}\text { Open hernia } \\
\text { repair }\end{array}$ & $\begin{array}{l}\text { Laparoscopic } \\
\text { hernia repair }\end{array}$ & P value \\
\hline
\end{tabular}

Mean duration of the sick leave (days)

$$
10.02 \pm 19.88 \quad 16.23 \pm 22.27 \quad 0.260
$$

Mean duration of returning to normal activity (days)

$$
36.12 \pm 58.55 \quad 34.59 \pm 44.97
$$

Mean duration of pain (days)

$$
20.81 \pm 39.06 \quad 5.68 \pm 6.87
$$

Comfort after the operation (0-10)

$$
8.95 \pm 1.36
$$$$
9.00 \pm 1.30
$$

direct hernia, one $(1.1 \%)$ - bilateral indirect hernia, and remaining two $(2.2 \%)$ - combination of direct hernia on one side, and indirect hernia on the contralateral side.

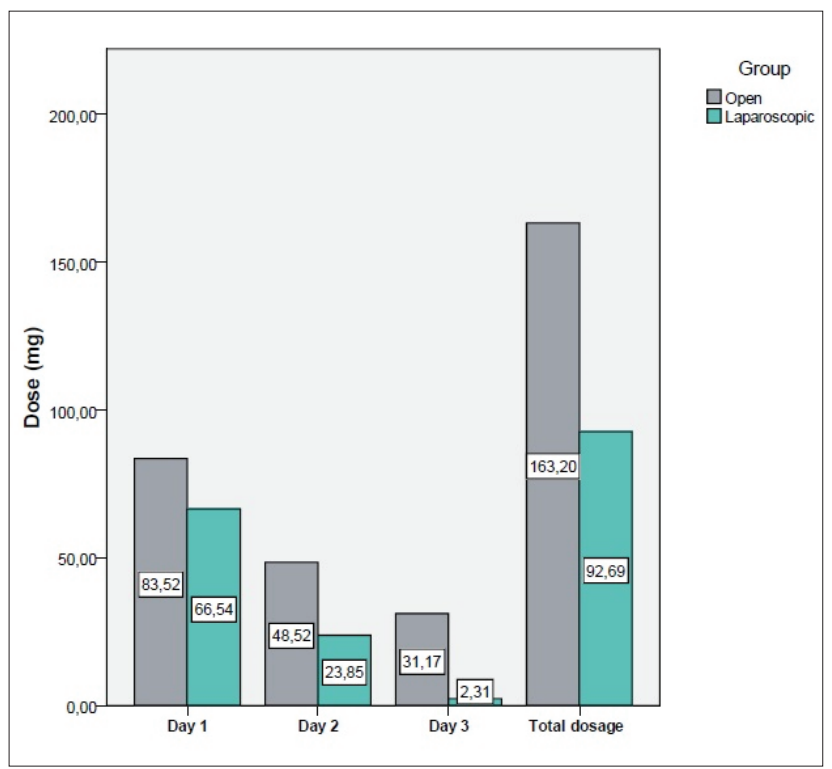

Figure 2. Use of NAID* postoperatively. All three postoperative days laparoscopically operated patients required lower doses of nonsteroidal anti-inflammatory drugs. The difference of the second and the third postoperative day mean dose of NAID and the total dosage between both groups was statistically significant $(\mathrm{p}=0.043, \mathrm{p}=0.000$ and $\mathrm{p}=0.008)$

*-NAID- nonsteroidal anti-inflammatory drugs (Ketonal, Ketanov, etc.)

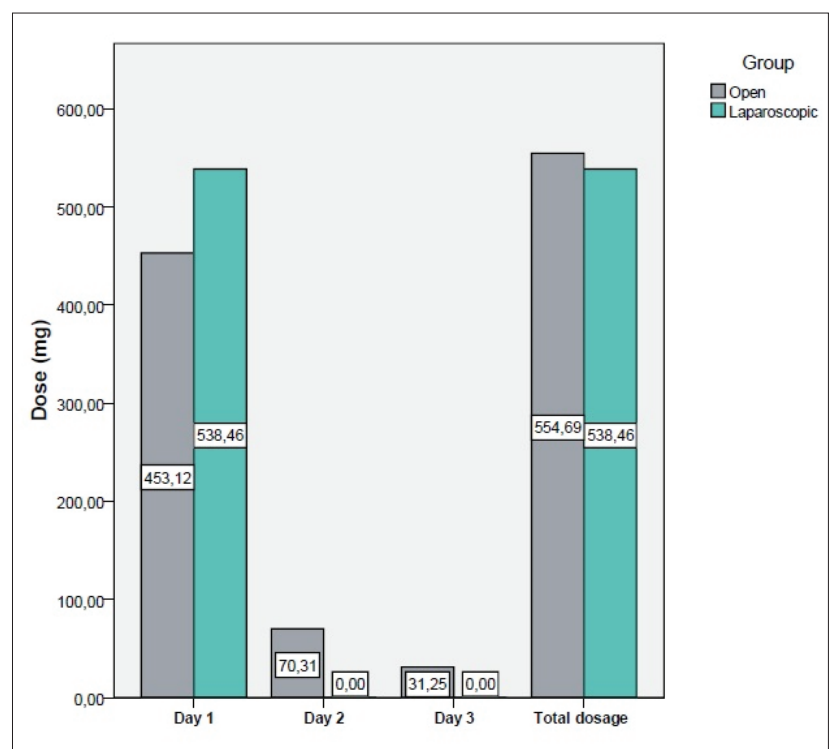

Figure 3. Use of Paracetamol postoperatively. There was no significantly difference by requirement for Paracetamol between each group. 
The pain score after laparoscopic surgery was lower according to the VAS on first, second and third day after the procedure (Table 2). The consumption of narcotic analgesics all three postoperative days was lower in laparoscopic group (see Fig.1): the first day in open surgery group the mean dose of opioids was $60.15 \pm 44.70 \mathrm{mg}$ while in laparoscopic group $50.00 \pm 28.28 \mathrm{mg}(\mathrm{p}=0,201)$; the second day $37.50 \pm 32.12 \mathrm{mg}$ compared with $28.84 \pm 25.19$ $\mathrm{mg}(\mathrm{p}=0.223)$; the third day $6.25 \pm 18.89 \mathrm{mg}$ compared with $0.00 \pm 0.00 \mathrm{mg}(\mathrm{p}=0.010)$.

All three postoperative days patients after laparoscopic hernia repair required lower doses of nonsteroidal antiinflammatory drugs (NAID), see Fig. 2: the mean dose of NAID first day was $83.51 \pm 66.37 \mathrm{mg}$ in open surgery group and $66.53 \pm 61.88 \mathrm{mg}$ in laparoscopic group $(\mathrm{p}=0.265)$; the second day $48.51 \pm 55.10 \mathrm{mg}$ compared with $23.84 \pm 42.12$ $\mathrm{mg}(\mathrm{p}=0.043)$; the third day $31.17 \pm 46.26 \mathrm{mg}$ compared with $2.30 \pm 8.15 \mathrm{mg}(\mathrm{p}=0.000)$.

There was no significantly difference by requirement for Paracetamol (first day $-\mathrm{p}=0.558$, second $-\mathrm{p}=0.118$ and third $-\mathrm{p}=0.527$ ) (see Fig.3).

The postoperative hospital stay was significantly shorter after laparoscopic repair: 19 patients of $26(73 \%)$ from laparoscopic surgery group and 27 of 64 (42\%) patients from open hernia repair group have spent less than 48 hours in the hospital $(\mathrm{p}=0.01)$. The mean inhospital stay in laparoscopic group was $1.5 \pm 0.82$ day and in open surgery group $3.2 \pm 2.53$ days.

Sixty-four patients $(71.11 \%)$ completed follow-up at one year after the operation. Nine (14.06 \%) of them had postoperative complications - two of them had more than one complication (see Table 3). Eight patients were from open surgery group and one from laparoscopic group. Four patients $(6.25 \%)$ had fever at home after discharge from the hospital, five patients $(7.81 \%)$ had wound infection. Surgical treatment for wound infection was not needed; there was enough changing of wound dressings. Two patients recorded the chronic pain in the area of hernia repair $(3.1 \%)$. Two patients $(3.1 \%)$ were re-operated: one for inguinal hernia recurrence $(2.38 \%$ of open surgery group, or $1.5 \%$ of all patients, who completed followup), another for testicular necrosis: both patients were from open hernia repair group (Lichtenstein method).

To classify all the complications we used The ClavienDindo classification. Grade I complications were recorded in 7 patients $(10.94 \%)$, no one patient had grade II or grade IIIa complications, and grade IIIb complications were recorded in 2 patients $(3.1 \%)$.

The patients after laparoscopic inguinal hernia repair returned to a normal daily activity a little earlier than pa- tients which undergone open surgery: days median in open surgery group was 21 ( $\max 365$ days) and in laparoscopic group - 14 ( $\max 180$ days). The time of the sick leave was longer in laparoscopic hernia repair group, but it was not statistically significant (see Table 4). The duration of pain in surgical wound area was significantly shorter between patients after laparoscopic procedure. Patient's satisfaction with the operation was a little better in laparoscopic group (see Table 4). The lowest mentioned satisfaction grade from 0 to 10 was 5 . Two patients gave 5 and were not satisfied with the outcome of the operation, because of the long lasting pain, hyperesthesia in the area of the postoperative scar (one patient from open surgery, another from laparoscopic group).

\section{Discussion}

There are numerous inguinal hernia repair techniques. It can be performed conventionally (open surgery) or in a minimally invasive way. Worldwide studies show that laparoscopic procedures are associated with less postoperative pain (1-4), with less analgesia consumption by the patient (13). Our study confirms these results: patients after laparoscopic TAPP repair had lower postoperative pain scores, required fewer analgesics, and the duration of the pain was shorter compared with open surgery.

Laparoscopic hernia repair is also associated with shorter hospital stay, faster recovery, earlier return to normal activities $(3,9)$. Better cosmetic results (4), possibilities to detect a contralateral inguinal defect and repair it through the same incision at the same time are the advantages of laparoscopic surgery too (9). The disadvantages of laparoscopic surgery include requirement of general anaesthesia, longer operative time and learning curve $(5,8,10,11)$, more expensive equipment (9). Findings of our study show that the operating time is longer for laparoscopic approach but this difference is clinically insignificant, however, the pain score for laparoscopic surgery was significantly lower according to VAS on day 1, 2, 3, the patients in the laparoscopic group required significantly lower doses of narcotic analgesics and nonsteroidal anti-inflammatory drugs, and the postoperative hospital stay was shorter after laparoscopic repair.

Surprisingly, the duration of the sick leave, the time required to return to normal activity in our study differs from other authors' results. The median of days required to return to daily activity in our study was 21 (max 365 days) in open surgery group and 14 (max 180 days) in laparoscopic group. Of course the variation between individual patients is wide. Liem et al. report the median in open group as $10(6-16)$ and in laparoscopic group- $6(4-10)(13)$. Our 
study results disclosed that the return to normal activity after the inguinal hernia repair lasts longer. We think it is a feature of Lithuania that people do not rush to return to the work, they extend the duration of the sick leave because they want to have more days off. There is a possibility of influence of the regional social traditions. The patients explained such a long sparing mode by the fear of hernia recurrence, also general practitioner suggestion avoid physical activities for about three-six month after the surgery. The other reason described was the absence of personal motivation for early return to the work. All these factors have a possible impact on our results of patients returning time to the work or to the physical activities. Because of the above mentioned regional specific features the comparison between Lithuanian regional studies or studies from Baltic region seems to be more reasonable.

We have found few inguinal hernia repair studies performed in Lithuania (14-16). Comparing with Lipnickas et al. data - they found laparoscopic TAPP procedures last longer, but all the patients left hospital earlier than the patients from an open surgery group (16). Our study revealed that the mean hospital stay in both laparoscopic and open surgery groups was shorter compared with Lipnickas et al. study: in our study the mean hospital stay in laparoscopic group was $1.5 \pm 0.82$ day, in open surgery group $3.2 \pm 2.53$ days compared with Lipnickas et al. study - laparoscopic group -4.2 days, Shouldice -4.7 and Lichtenstein -5.1 days. This difference could be explained because Lipnickas et al. study was performed almost 10 years ago, when day surgery procedures in Lithuania were just starting their first steps and it was common to keep the patient for a longer time in a hospital compared with nowadays. Another reason could be that our study was done in one surgery centre - Hospital of LUHS, when Lipnickas et al. study was multicenter - all hospitals have different patient treatment politics. Another Lithuanian study also revealed longer hospital stay (3.28 2.239$)$ in laparoscopic (TAPP) patients group compared with our study (15).

Complications of laparoscopic and open inguinal hernia repair techniques can be divided in two groups: intraoperative and postoperative. Intraoperative complications belong from chosen surgery technique and can be - bladder injury, bowel injury, vascular injury, injury to Vas Deferens, etc (4). The main postoperative complications can be seroma/hematoma formation, neuralgias, mesh infection, wound infection, testicular pain and swelling, recurrence $(4,13)$. Nine of 64 patients in our study had postoperative complications: 5 of them (7.81\%) had wound infection. It is higher number compared with another Lithuanian study where wound infection two weeks after the surgery was just 1.2 percent (16). The most unpleasant complication observed in our study was after Lichtenstein method surgery - it was testicular necrosis which had lead to removal of the testis.

The most important endpoint of laparoscopic and open surgery is inguinal hernia recurrence. We found one hernia recurrence among patients in our study at one year followup. The recurrence occurred after open inguinal hernia repair. The recurrence rate after the open Lichtenstein mesh repair according the literature is $1-1.4 \%$ (17). Compared with other Lithuania surgery centre (Stanaitis et al. study) we had bigger recurrence rate after Lichtenstein procedure (our 2.38 percent vs 0.96 percent Stanaitis et al.). However we did not had any recurrence in Shouldice or laparoscopic TAPP group (Stanaitis et al.study revealed the recurrence rate $0.98 \%$ after Shouldice procedure and $1.8 \%$ after TAPP) (14).

One more unexpected finding in our study- patients described their comfort after open and laparoscopic procedures almost the same (mean evaluation in open surgery group was 8.95 and in laparoscopic group 9.00) despite that in laparoscopic group patients had shorter pain duration, the pain severity was lower, they returned to daily activity earlier. We expected to find a more significant difference between open and laparoscopic groups evaluating the postoperative comfort. It is difficult to explain why the satisfaction grade after the procedure is almost the same in both groups.

\section{Conclusions}

1. Surgery type does not depend on patient's gender or the side of hernia.

2. For patients, who were younger, had shorter history of presence of inguinal hernia, laparoscopic procedure was done significantly more often.

3 . The pain score after laparoscopic surgery was significantly lower according to VAS on day 1,2, 3. The need of analgesics all three days was lower in laparoscopic group.

4. The postoperative hospital stay was significantly shorter after laparoscopic repair.

5. After laparoscopic surgery patients had shorter pain duration, returned to daily activity earlier and had better satisfaction with the operation, however the duration of the sick leave was longer in laparoscopic hernia repair group.

\section{References}

1. Kavic SM. Laparoscopic versus open repair: a superior approach to inguinal herniorrhaphy? OA Min Inv Surg 2013; 1(1):1. https://doi.org/10.13172/2054-2666-1-1-618

2. Stoker DL, Speigelhalter DJ, Singh R, Wellwood JM. La- 
paroscopic versus open inguinal hernia repair: randomised prospective trial. The Lancet 1994; 343 (8908): 1243-1245. https://doi.org/10.1016/S0140-6736(94)92148-2

3. Karthikesalingam A, Markar SR, Holt PJE, Praseedom RK. Meta-analysis of randomized controlled trials comparing laparoscopic with open mesh repair of recurrent inguinal hernia. British Journal of Surgery 2010; 97(1): 4-11

https://doi.org/10.1002/bjs.6902

4. Fegade S. Laparoscopic versus open repair of inguinal hernia. World Journal of Laparoscopic Surgery 2008; 1 (1):41-48 https://doi.org/10.5005/jp-journals-10007-1046

5. Schmedt CG, Sauerland S, Bittner R. Comparison of endoscopic procedures vs Lichtenstein and other open mesh techniques for inguinal hernia repair: a meta-analysis of randomized controlled trials. Surg Endosc and other Interventional Techniques 2005; 19: 188-199 . DOI: 10.1007/s00464-004-9126-0 https://doi.org/10.1007/s00464-004-9126-0

6. Castorina S, Luca T, Privitera G, El-Bernawi H. An evidence-based approach for laparoscopic inguinal hernia repair: lessons learned from over 1,000 repairs. Clin Anat. 2012; 25(6):687-696. https://doi.org/10.1002/ca.22022

7. Bittner R, Schwarz J. Inguinal hernia repair: current surgical techniques. Langenbeck's Arch Surg 2012; 397(2):271-282. https://doi.org/10.1007/s00423-011-0875-7

8. Memon MA, Cooper NJ, Memon B, Memon MI, Abrams KR. Meta-analysis of randomized clinical trials comparing open and laparoscopic inguinal hernia repair; British Journal of Surgery 2003; 90 (12): 1479-1492.

https://doi.org/10.1002/bjs.4301

9. Perko Z, Rakic M, Pogorelic Z, Družijanic N, Kraljevic J. Laparoscopic transabdominal preperitoneal approach for inguinal hernia repair: a five-year experience at a single center. Surg Today $2011 ; 41(2): 216-221$.

https://doi.org/10.1007/s00595-010-4266-4

10. Kulacoglu H. Current options in inguinal hernia repair in adult patients. Hippokratia 2011; 15 (3): 223-231.

11. Carter J, Duh QY. Laparoscopic repair of inguinal hernias. World J Surg 2011; 35(7):1519-1525. https://doi.org/10.1007/s00268-011-1030-x

12. Köckerling F, Schug-Pass C. Tailored approach in inguinal hernia repair - decision tree based on the guidelines. Frontiers in Surgery | Visceral Surgery 2014; 1:20 doi: 10.3389/ fsurg.2014.00020 https://doi.org/10.3389/fsurg.2014.00020

13. Liem MS, Van Der GraafY, Van Steensel CJ, Boelhouwer RU, Clevers GJ, Meijer WS, Stassen LPS, Vente JP, Weidema WF, Schrijvers AJP, Van Vroonhoven TJ. Comparision of conventional anterior surgery and laparoscopic surgery for inguinalhernia repair. N Engl J Med 1997; 336(22):1541-1547. https://doi.org/10.1056/NEJM199705293362201

14. Stanaitis J, Lunevičius R. Kokị operacijos būdą pasirinkti operuojant kirkšnies išvaržas? Lietuvos chirurgija, 2008; 6(2):107-111.

15. Narmontas D, Gradauskas A. Laparoskopinè hernioplastika Vilniaus miesto universitetinèje ligoninèje. Medicinos teorija ir praktika, 2010; 16(4), 424-430.

16. Lipnickas V, Kiudelis M, Gradauskas A, Kaselis N, Strupas K. Shouldice, Lichtensteino ir laparoskopinių transabdominalinių preperitoninių kirkšninių išvaržų operacijų ankstyvieji rezultatai: daugiacentrinis atsitiktinių imčių klinikinis tyrimas. Lietuvos chirurgija, 2006; 4(4), 247-258.

17. Bittner R,Schwarz J. Inguinal hernia repair:current surgical techniques. Langenbeck's Arch Surg 2012; 397(2):271-282. https://oi.org/10.1007/s00423-011-0875-7

\section{Cuts and bits}

Ninety consecutive patients who underwent inguinal hernia repair were included in the prospective study. Age, sex, body mass index, hernia type, duration of symptoms were recorded before surgery. Duration of procedure, postoperative pain first, second and third day after the operation, duration of postoperative pain, comfort after the procedure, presence of complications, reoperation rate, duration of the sick leave, duration of returning to normal activity and recurrence rate were investigated during follow-up visits after the operation.

\section{LAPAROSKOPINĖS IR ATVIROS KIRKŠNIES IŠVARŽOS PLASTIKO PALYGINIMAS \\ Ž. Dambrauskas, L. Pankratjevaitė, V. Bogusevičius, A. Mickevičius}

Raktažodžiai: laparoskopinė hernioplastika, atvira kirkšnies išvaržos plastika, pooperacinis skausmas, komplikacijos

Santrauka

Kirkšnies išvaržos plastika - viena dažniausių chirurginių procedūrų. Laparoskopinè kirkšnies išvaržos plastika techniškai sunkiau ịvaldoma, siejama su mažesniu pooperaciniu skausmu bei diskomfortu, tačiau atkryčio dažnis, lyginant su ịprasta kirkšnies išvaržos plastika, yra ganėtinai panašus. Siekdami išsiaiškinti laparoskopinès hernioplastikos naudą, palyginome pooperacinio skausmo dydi, artimuosius ir tolimuosius rezultatus po atviros kirkšnies išvaržos operacijos ir laparoskopinès procedūros. Mūsų gauti rezultatai parodè, kad laparoskopinè hernioplastika dažniau atliekama jaunesniems, trumpiau sirgusiems pacientams, tačiau operacijos trukmė šioje grupėje ilgesnè $(p=0,02)$. Laparoskopiškai operuoti pacientai pirmas tris dienas jautè silpnesnị pooperacinị skausmą vertinant pagal vizualinę analoginę skalę $(\mathrm{p} \leq 0,002)$. Po laparoskopinès operacijos trečią pooperacinę parą pacientai reikalavo statistiškai reikšmingai mažesnès narkotinių analgetikų dozès, o antrą ir trečią pooperacinę parą- nesteroidinių vaistų nuo uždegimo. Taip pat laparoskopiškai operuoti pacientai ligoninejje praleido trumpesnị laiką nei tie pacientai, kuriems atlikta atvira kirkšnies išvaržos plastika $(p=0.01)$. Šešiasdešimt keturi $(71,11 \%)$ pacientai buvo pakartotinai ištirti vienerių metų laikotarpiu po ope- 


\section{4}

racijos. Devyniems (14,06\%) pacientams, iš kurių aštuoniems buvo atlikta atvira kirkšnies išvaržos plastika, pasireiške pooperacinės komplikacijos. Du $(3,1 \%)$ pacientai (abiems atlikta kirkšnies išvaržos plastika tinkleliu) peroperuoti: vienas dèl išvaržos recidyvo, kitas dèl sèklidès nekrozès.

Išvados: laparoskopiškai operuoti pacientai daug trumpiau jautė pooperacinį skausmą ( $\mathrm{p}=0,019)$, šiek tiek anksčiau sugrị̌o ị aktyvų kasdienini gyvenimą, jautèsi geriau nei pacientai, kuriems atlikta iprastinė kirkšnies išvaržos plastika ( $\mathrm{p}=0,915, \mathrm{p}=0,893)$, tačiau nedarbingumo trukmė buvo panaši abiejose grupèse $(p=0,260)$. Mūsų gauti duomenys rodo, jog laparoskopinès kirkšnies išvaržos plastikos privalumai yra silpnesnis, trumpiau besitęsiantis pooperacinis skausmas, mažesnè komplikacijų tikimybė bei didesnis pacientų pasitenkinimas operacija ir jos rezultatais.

Adresas susirašinėti: zilvinas.dambrauskas@gmail.com

Gauta 2016-11-15 